\title{
SPOKOJENOST V DLOUHODOBÝCH PARTNERSKÝCH VZTAZÍCH: KVALITATIVNÍ STUDIE ČESKÝCH HETEROSEXUÁLNÍCH PÁRŮ
}

\author{
ZUZANA KALOUSOVÁ, IVA ŠTĚTOVSKÁ
}

\begin{abstract}
Abstrakt: Tento článek prezentuje výsledky kvalitativní studie, která zkoumala české spokojené páry. Výsledky tohoto šetření jsou porovnány s poznatky zahraničních studií. V první části textu je stručný úvod do dosavadních poznatků v oblasti spokojenosti v partnerských vztazích a přehled zahraničních studií s podobným designem. Dále je popsán výzkum, který byl uskutečněn v rámci diplomové práce Zuzany Kalousové v roce 2017. Jednalo se o kvalitativní výzkum, v rámci kterého byly vedeny polostrukturované rozhovory s 22 respondenty žijícími ve spokojeném vztahu po dobu více než deseti let. $\mathrm{K}$ analýze materiálů byla použita technika zakotvené teorie. Výsledkem bylo deset kategorií, které přispívaly ke spokojenosti ve vztazích respondentů: překonání rozdílů a překážek, společné aktivity, komunikace, vytrvalost, neřešit vše, soulad, bezpečí, dobrá volba partnera/ky, stabilní ekonomická situace, rodina.

Klíčová slova: spokojenost v partnerských vztazích, manželské přizpůsobení, kvalitativní výzkum, české páry
\end{abstract}

The Satisfaction in Longterm Romantic Relationships: A Qualitative Study of Heterosexual Czech Couples

Abstract: This article presents the results of the qualitative research, which pursued the topic of satisfaction in relationships in Czech couples. The results are compared with the outcomes of several studies from abroad. The first part of the paper consists of a brief introduction to the topic and present the results of studies with a similar design. The second part describes the research, which was part of Zuzana Kalousova's thesis in 2017. It is a qualitative research conducted via half-structured interviews with 22 respondents who have been in a satisfactory relationship for over ten years. To analyze the data, we used grounded theory. The results were ten categories that contributed to satisfaction in relationships: overcoming of differences and obstacles, doing things together, communication, endurance, not trying to solve everything, harmony, safety, good choice of spouse, stable financial situation, family.

Key words: Satisfaction in romantic relationship, marital adjustment, qualitative research, Czech couples

https://oi.org/10.14712/23366486.2021.8

\section{Úvod a teoretické zázemí}

V tomto článku prezentujeme kvalitativní studii spokojenosti v partnerských vztazích jedenácti českých heterosexuálních párů a srovnání výsledků této studie s podobnými zahraničními výzkumy. Zkoumání spokojenosti v partnerských vztazích není snadným 
úkolem, protože jde o konstrukt vysoce subjektivní povahy, označovaný různými termíny (partnerská/manželská spokojenost, štastné páry, partnerské/manželské štěstí, kvalita manželského/partnerského vztahu atd.), obtižně operacionalizovatelný a měřitelný. Dá se vnímat jako konstrukt jednodimenzionální nebo vícedimenzionální, lze na něj pohlížet z interpersonálního i intrapersonálního hlediska.

První vědecké práce, které si kladly za cíl nalézat koreláty manželské spokojenosti (Davis, 1929; Bernard, 1933, 1934; Terman a Johnson, 1939 atd.) daly vzniknout termínu manželské přizpůsobení (marital adjustment), který předcházel ostatním výše zmíněných výrazům. Manželské přizpůsobení je multidimenzionální konstrukt a jednou z jeho složek je spokojenost. Již Terman a Johnson (1939) však používali výrazy manželské přizpůsobení (marital adustment), manželská spokojenost (marital satisfaction) a manželské štěstí (marital happiness) jako synonyma. Locke a Wallace (1959) vytvořili k měření manželského přizpůsobení Marital adjustment test (MAT), a odstartovali tak éru vědeckého zkoumání tohoto konstruktu. MAT se stal stavebním kamenem pro další metody měření manželské a partnerské spokojenosti. V roce 1976 vydal Spanier Dyadic adjustment scale (DAS), který překonával některé nedostatky svého předchůdce. Tyto dvě metody zde uvádíme, protože byly významné pro počátky vědeckého zkoumání spokojenosti v partnerských vztazích, a také protože ilustrují obtížnost operacionalizování tohoto konstruktu, která přetrvává do dnešní doby, a odráží se např́ílad v tom, že tyto metody, které měří manželské přizpůsobení, jsou použivány jako zlatý standard pro vývoj testů měřících spokojenost a kvalitu vztahu. Ward, Lundberg, Zabriskie a Berrett (2009) kritizují užívání různorodých inventářů pro měření stejného konstruktu a zdůrazňují nutnost ustanovit jednoznačnou definici konstruktu manželské spokojenosti. Přicházejí s formulací, že manželská spokojenost je: ,emočni stav jednotlivce, ve kterém se cítí spokojený s interakcemi, zážitky a očekáváním od manželského života " (Ward, Lundberg, Zabriskie a Berrett, 2009, str. 414). V Encyklopedii výzkumu kvality života a well-beingu je spokojenost v partnerských vztazích definována jako: ,,subjektivni hodnocení vztahu jedince. Nejde o vlastnost vztahu, jde o subjektivní zážitek a názor. Proto se u členů stejné dvojice může lišit, jak jsou spokojeni se vztahem " (Keizer, 2014).

Spokojenost v partnerských vztazích je spojována s mnoha benefity z oblasti zdraví a osobní pohody (Gottman a Gottman, 2017; Rahn, Bennett, Jones a Lykins, 2019; Shrout et al, 2020). Dokonce samotné očekávání budoucí spokojenosti se vztahem má podle Bakera, VanderDrifta a McNultyho (2017) souvislost se závazkem. $Z$ těchto poznatků vychází potřeba zkoumat př́ipady, kde partnerství dlouhodobě naplňuje oba členy svazku spokojeností. O nutnosti zaměřit se na zkoumání specifických aspektů funkčních vztahů mluví i Bachandová a Caronová (2001), Gottman et al. (1998) nebo Rauerová a Vollingová (2013).

V této části popíšeme zahraniční kvalitativní studie podobného charakteru, které byly nalezené metodou sběhové koule v letech 2016 a 2020 v databázích př́stupných na Portálu elektronických zdrojů Univerzity Karlovy.

Wallersteinová (1996) uskutečnila studii s 50 spokojenými páry. Vedla rozhovory s účastníky jednotlivě i dohromady. Výsledkem bylo devět úkolů či výzev, které je zapotřebí zvládnout, aby bylo manželství spokojené a stabilní: emocionálně se odpoutat od původní rodiny a plně se věnovat nové rodině, budovat společnou sounáležitost (togetherness) a intimitu, vést uspokojivý sexuální život, přijmout zodpovědnost přicházející s rodičovskou rolí, překonat nevyhnutelné krize, vytvořit bezpečnou zónu pro 
vyjádření emocí, užívat humor k udržení nadhledu, pečovat o partnera a udržovat romantiku.

Allendorfová (2012) dělala kvalitativní výzkum manželské spokojenosti na indickém venkově. Jejím záměrem bylo poskytnout srovnání manželské spokojenosti v západních a východních zemích. Analyzovala rozhovory z 22 venkovských domácností (46 respondentů). Autorka odhalila tyto faktory přispívající manželské spokojenosti: láska, porozumění (understanding), klid (peace), důvěra a věrnost, komunikace, rovnováha (ballancemíněno rovnováha mezi láskou k ženě a ke svým rodičům).

Bachandová a Caronová (2001) provedly kvalitativní studii na vzorku 15 heterosexuálních párů, které byly sezdány po dobu více než 38 let a označovaly své soužití za št’astné. Všechny páry měly alespoň jedno dítě a jednalo se o jejich první manželství. Autorky kladly nejprve obecnou otázku, jak si účastníci vysvětlují dlouhodobost svého vztahu, a poté se zajímali o některá témata, která vyplynula z literárního přehledu. Zde jsou kódované odpovědi účastníků na otázku, jaké faktory přispěly k dlouhodobosti jejich vztahu: přátelství, láska, stejné zázemí/zájmy, závazek, svoboda jít si za svými cíli, znát druhého dobře z doby před vztahem, respekt pro druhého, podobné hodnoty, partner je dobrý člověk, pozornost k pocitům druhého, podpora, akceptance/tolerance, náboženství/shoda ve víře, kamarádství (partnership), důvěra, děti, komunikace, loajalita, trpělivost, sounáležitost (companionship), kompromis, odpuštění, stavět druhého na první místo.

Daneshpourová a další (2011) chtěli zjistit, jaké faktory přispívají št’astnému manželství. Jejich vzorek čítal 11 párů, které spolu byly více než 10 let. Výzkumníci formulovali tyto faktory, které napomáhají spokojenosti v dlouhodobém vztahu: páry si věří a jsou si oddaní, mluví spolu (consult with each other), vnímají svůj vztah jako intimní, řeší své problémy, kooperují spolu ve výchově dětí, sdílejí společnou víru/názory (beliefs), vyjadřují si vzájemně lásku.

\section{Metodologie}

Výzkumnou otázkou, kterou jsme si kladly, bylo: Co činí dlouhodobé partnerské vztahy spokojenými? Prezentovaný výzkum byl vypracovaný v rámci diplomové práce Kalousové (2017). Sběr dat probíhal metodou polostrukturovaného rozhovoru. Rozhovor byl veden s každým z partnerů zvlášt’ a na závěr bylo krátké setkání s oběma dohromady. Doplňující technikou k rozhovoru bylo grafické znázornění spokojenosti a společné sestavování seznamu faktorů spokojenosti. Sběr dat probíhal od listopadu 2016 do února 2017. Většina rozhovorů probíhala u respondentů doma. Na samém začátku byli účastníci požádáni, aby zaznamenali míru současné spokojenosti ve vztahu na škále od 0 do 10 , kde deset je nejspokojenější.

Zpracování získaných dat proběhlo podle zásad zakotvené teorie. Při přepisování rozhovorů byla provedena redukce prvního řádu, poté bylo provedeno otevřené, axiální a selektivní kódování. Jednotlivé výroky byly kódovány a vznikly podkategorie, které byly posléze sloučeny do kategorií podle podobnosti, souvislostí a kontextu. Proces kódování a přezkoumávání příslušnosti ke kategoriím byl opakován několikrát, než vznikly výsledky, které byly ještě ověřené triangulací. 


\section{Výsledky}

Výběr respondentů proběhl metodou samovýběru a následně metodou sněhové koule. Respondenti ve výzkumném souboru museli být ve vztahu trvajícím alespoň 10 let, kde oba z partnerů považují svůj vztah za spokojený (na škále od nuly do deseti, kde deset je nejspokojenější, oba z partnerů uvedou číslo sedm a vyšší).

Výzkumný vzorek činil 22 respondentů z 11 párů žijících v České republice. Průměrný věk účastníků byl 35,6 let s rozpětím od 28 do 59 let. Délka vztahu účastníků byla od 10 do 38 let, průměrně 15,6 let. Dva páry žily v nesezdaném soužití, zbylí respondenti byli manželé. Pro všechny sezdané páry to bylo první manželství. Průměrná spokojenost respondentů ve vztahu na škále os 0 do 10 byla 9,3. Podmínkou pro zařazení do výzkumu bylo číslo sedm.

Dva respondenti byli vyučení, 10 mělo středoškolské vzdělání a 10 vysokoškolské vzdělání. Dva páry neměly žádné děti, tři páry jedno dítě, pět párů dvě děti a jeden pár tři děti. Tři páry bydlely v Praze, čtyři v jiném českém městě a čtyři na vesnici.

Odpovědi respondentů se výrazně nelišily podle pohlaví. Žádná z kategorií ani podkategorií nebyla významně ženská či mužská. Nelze říct, že by se odpovědi uvnitř páru shodovaly ani odlišovaly. Respondenti udali odpověd' ve stejné podkategorii jako jejich partner průměrně šestkrát v průběhu rozhovoru, přičemž rozptyl byl od 3 do 11 souhlasných výroků.

Výsledkem studie je 32 podkategorií seskupených do 10 kategorií.

PŘEKONÁNÍ ROZDÍLŮ A PŘEKÁŽEK. Tato kategorie zahrnuje přizpůsobení se, ochotu ustoupit, toleranci a také společné překonání př̌kážek, které vede ke stmelení vztahu. Velmi často se ve výrocích respondentů objevovalo slovo kompromis nebo ochota ustoupit. Hojně používaným slovem byla i tolerance. V rozhovorech s respondenty často zaznívalo, jak partnery posílilo a stmelilo překonávání překážek. Také z toho bylo patrné, že nešlo o žádné extaticky št'astné jedince, ale že se také museli potýkat s problémy a řešit společně výzvy, které jim život připravil.

SPOLEČNÉ AKTIVITY. Kategorie společné aktivity je tvořena dvěma poměrně silně zastoupenými podkategoriemi: aktivity zaměřené na společnou budoucnost a společné trávení volného času. Jsou zde zařazeny výroky, ve kterých účastníci popisovali společné aktivity, společné pracovní činnosti, plánování budoucnosti a naplňování společných cílů, podnikání různých aktivit s dětmi apod. Zmiňovali, jak pro ně bylo důležité posouvat jejich vztah dál, neustrnout, ,nepřechodit se“. Lidé spokojení se svým vztahem často zmiňovali, že podnikají určité kroky pro to, aby si spokojenost udrželi: ,, snažím se do toho vztahu, co jde dávat“, „dbám o to, aby vztah kvetl“.

KOMUNIKACE. Několikrát došlo v průběhu sběru dat na zvolání: „komunikovat, komunikovat, komunikovat!“ Patří sem podkategorie: mluvení a naslouchání, vyř́ikat si to, upř́imnost a humor. Mluvení a naslouchání je podkategorie, kde byla komunikace zmiňována v obecném slova smyslu. Jsou to výroky, kde se několikrát opakuje samotné slovo komunikace, obecná potřeba partnerů spolu mluvit a její souvislost se spokojeností ve vztahu. Početné byly výroky o komunikaci při řešení problémů. Respondenti zmiňovali různé způsoby, jak si vzájemné neshody vyříkat, vysvětlit, rozebrat. Legrace je podkategorie, která se neobjevovala v rozhovorech hned od začátku, spíš se vynořovala postupně. Také není tak soudržná jako jiná témata. Objevovala se tvrzení: „že se hodně směje“, „rádi se spolu bavíme, smějeme se... “. Za důležitou považovali spokojení 
partneři i upřímnost. Mluvili o tom, že je třeba vše říkat na rovinu, být poctivý, nelhat. Na svých partnerech oceňovali, že jsou uprímní.

VYTRVALOST. Zde jsou zařazena témata čas, vytrvalost/trpělivost a rozhodnutí/zodpovědnost. Možná se to může zdát překvapivé, ale někteří respondenti přičítali svou spokojenost na vrub samotnému času. Používali obraty jako: ,časem se to tak nějak srovná “, „čas je největší lékař “ nebo ,čas všechno vyřeši “. Pod názvem výdrž/trpělivost si můžeme docela dobře představit známé rčení, které je součástí manželského slibu: „, dobrém i ve zlém, ve zdraví i v nemoci..." Respondenti se rozhodli, že budou spolu, přistoupili ke vztahu zodpovědně a byli ochotni v něm vytrvat a překonat př́padné překážky.

NEŘEŠIT VŠE je kategorie méně soudržná, trochu kontroverzní, ale poměrně hojně sycená odpověd'mi. Vychází ze svědectví některých účastníků o tom, že pro zachování spokojenosti a domácí pohody je někdy zapotřebí něco vypustit, přejít, nevytvářet problémy, zachovat klid, dát partnerovi prostor, spokojit se s tím, co je, nehledat důvody pro rozchod apod. Patří sem podkategorie: neřešit vše, klid, není důvod se rozejít, nepřítomnost konfliktů a prostor partnerovi. V podkategorii nazvané neřešit vše jsou shromážděny výroky typu: „neřeším hlouposti “, „,každý vztah má nějaké mouchy a já to neřešim “. Dalším rozměrem této podkategorie je, že by člověk neměl chtít moc, že je někdy lepší se spokojit s tím, co má, vážit si toho, co má. V rozhovorech zaznívalo, že partner, partnerka nebo oba jsou klidní, vyrovnaní, dokonce flegmatičtí. Další podkategorie nese název „není důvod se rozejít“. Ačkoli se to může zdát paradoxní, ve faktorech spokojenosti v partnerském vztahu je zařazena i tato oblast, protože respondenti uváděli, že prostě nemají důvod vztah s partnerem ukončit.

Kategorie SOULAD má pod sebou tři podkategorie, jež jsou: sedli jsme si/doplňujeme se/zapadlo to, rozumíme si a stejné cíle. Spokojení partneři vypovídali, že jsou v souladu, sedli si, rozumí si, prostě jim to všechno zapadá. Partneři však zároveň popírali, že by si byli vzájemně hodně podobní. Podkategorii „rozumíme si“ tvoří výroky o tom, že se partneři shodnou, jsou za jedno. Do podkategorie stejné cíle spadají např́íklad výroky: „, byli jsme na stejné vlně, stejné cíle“ nebo „od začátku víme, že do budoucna chceme to samé".

Do kategorie BEZPEČÍ patři podkategorie důvěra, opora/podpora a ohleduplnost/ být hodný na partnera. Důvěra byla zmiňovaná v několika podobách. Jednak v obecné rovině, tedy potřeba si navzájem věřit, ale zahrnovala také věrnost, která je s důvěrou spjatá. Respondenti zmiňovali důvěru v souvislosti se spolehlivostí a s tím, že není nutné dělat žárlivé scény a že jsou si jisti partnerovou věrností, což přispívalo k pocitu bezpečí ve vztahu. Ilustruje to například tvrzení: ,vím, že by mě v životě nepodvedl, můžu mu stoprocentně věrit. “ Podkategorie opory/podpory je sycena tvrzeními typu: ,je taková velká opora“, , stála za mnou“. Další podkategorií je ohleduplnost/být hodný na partnera. Respondenti ji vyjadřovali slovy: ,, ohledy na druhého “, ,ohleduplnost“, ,, starostlivost".

DOBRÁ VOLBA PARTNERA. Zařazeny jsou sem podkategorie dobrá volba, všechno mám na ní/něm ráda a láska. Dobrá volba a dobrý partner se v rozhovorech manifestovaly výroky typu: ,, možná jsem potkala toho správného chlapa “. Velmi zajímavou podkategorií byly výroky, které vyjadřovaly vzájemnou náklonnost variacemi na téma: všechno mám na ní/něm rád/a. Respondenti říkali například: „,Já má ráda všechno, co dělá, neumím to konkretizovat. "Do této kategorie je zařazena i láska. Jde o několik málo výroků př́mo či nepř́mo odkazujících na vzájemné city. Samotné slovo láska se moc často neobjevovalo. 
Dvakrát uvedli respondenti lásku za jeden z faktorů partnerské spokojenosti, třikrát se ozval výraz zamilovanost, dvakrát mít se rádi a jednou milujeme se.

EKONOMICKÉ FAKTORY se dělí na podkategorie hospodaření s penězi a samostatná domácnost. Několik respondentů uvedlo, že se jejich spokojenost se vztahem výrazně zvýšila, když se osamostatnili od rodičů nebo přestěhovali do vhodnějšího bydlení, koupili byt nebo dům apod.

RODINA. Tato kategorie v sobě zahrnuje tři podkategorie: teplo domova, děti a původní rodinu. Příchod dětí byl respondenty většinou vnímán jako událost, která zvýšila jejich spokojenost, někdy poměrně markantním způsobem. Dle slov respondentů ovlivnila původní rodina spokojenost v jejich současném vztahu dvěma způsoby, bud' získali partneři od svých rodičů dobrý př́klad a chtěli ho následovat, nebo se naopak snažili vyvarovat chyb svých rodičů.

\section{Diskuze}

V prezentovaných výsledcích výzkumu se nevynořila dvě témata, která nalézáme u jiných autorů, a to jsou sex a náboženství. Téměř úplnou nepřítomnost výroků obsahujících jakoukoli explicitní zmínku o sexuálním soužití přičítáme na vrub tomu, že se respondenti mohli ostýchat a krátký čas rozhovoru jim nedal dostatek prostoru vybudovat si dostatečnou důvěru. Např́klad Simsová a Meana (2010) ve výsledcích svého výzkumu konstatovaly, že neuspokojivý sexuální život jejich respondentkám nebránil, aby byly ve svém vztahu celkově spokojené.

Ačkoli u zahraničních autorů hrálo mnohdy významnou roli náboženství a společná víra, v našem výzkumu se o náboženství žádný respondent nezmínil. Bachandová a Caronová (2001) měly náboženství/shodu ve víře na 13. místě. Nepřítomnost odpovědí týkajících se náboženství mohla být zapř́íciněna kulturním kontextem. Na druhou stranu, pokud bychom odhlédli od náboženství jako instituce, a spíše se zaměřili na společnou víru, postoje, hodnoty a cíle partnerů jako např́íklad Daneshpourová a další (2011), kteří provedli toto propojení náboženství a víry v obecnějším slova smyslu (beliefs), potom bychom ekvivalent ve výsledcích představeného výzkumu našli v kategorii soulad.

V kategorii bezpečí se několik výzkumů potkává v podkategorii důvěra. Allendorfová (2012) vytvořila kategorii ze spojení důvěra a věrnost. V př́padě zde prezentované práce je důvěra spojena s věrností, protože ve výpovědích respondentů k sobě měly tyto dva konstrukty blízko, kdežto upřímnost je zařazena ke kategorii komunikace. Další z průsečíků této studie a odborné literatury nalezneme v podkategorii podpora. O tom, že ve spokojeném vztahu je zapotřebí podporovat se navzájem, píší např́klad autoři Yedirirová a Hamarta (2015) a Wallersteinová (1996).

V podkategorii ,soulad“ byla jedna z podkategorií „sedli jsme si, doplňujeme se, zapadlo to“. Podobná koncepce se objevila ve výzkumu Walersteinové (1996), jejíž respondenti uváděli, že ve št’astném manželství partneři sdílí společný pocit, že našli nebo dosáhli dobré shody s partnerem (good fit), sdílejí stejná či podobná přání, potřeby a očekáváními. Do této kategorie spadá i láska. Autoři výše uvedených zahraničních výzkumů však většinou lásku uvádí samostatně (Allendorf, 2012), nebo dokonce na prvních místech důležitosti (Bachand \& Caron, 2001). Je možné, že v naší kultuře není tak obvyklé vyjadřovat city přímo skrz slova mám tě rád či miluji tě, jako kdybychom těmito výrazy spíše chtěli šetřit. 
Kategorie překonání rozdílů a překážek se potkává s výsledky Bachandové a Caronové (2001) a Wallersteinové (1996), která píše, že je zapotřebí konfrontovat se s nevyhnutelností krizí, zvládnout je a zachovat si partnerské pouto.

Společné trávení času, činorodost a společné zážitky uvedlo jako stmelující faktor mnoho respondentů. V odborné literatuře se objevují podobné výsledky např́klad u Arona et al. (2000) a Grahama (2008). Zajímavé je, že v kvalitativních studiích uvedených výše mnoho zmínek o společném trávení času a zábavě není. Pouze Bachandová a Caronová (2001) mají v seznamu faktorů společné zázemí/zájmy.

K podobným výsledkům v oblasti komunikace dospěla Allendorfová (2012). Daneshpourová et al. (2011) zmiňují, že z počátku se respondenti hodně hádali a neřešili a málo komunikovali, časem se to vylepšilo.

V kategorii neřešit vše lze spatřit jistou podobnost s konceptem zaměření na maximalizaci (maximization) a satisfakci (satisfaction). Podle Mikkelsona a Pauleyho (2013) jsou ve vztazích št’astnější ti lidé, kteří se spokojí s dostupnou variantou, pokud naplňuje jejich potřeby a nehledají tu nejlepší možnou variantu. Podobně respondenti v tomto výzkumu uváděli, že nevidí důvod měnit partnera, dělat ze všeho vědu, řešit zbytečnosti. Dovedli se přenést přes nedostatky vztahu nebo toho druhého a být spokojeni s tím, co mají. Také je zde jistá podobnost v podkategorii klid se stejnojmennou kategorií u Allendorfová (2012).

Projekty zkoumání spokojenosti v partnerských vztazích s sebou nesou mnoho pochybností, zda a jakým způsobem je vůbec možné je smysluplně realizovat. Když pomineme úskalí, která s sebou nese samotné vymezení termínů a ustálení jednotného pojmenování partnerské spokojenosti, jsou tu další zásadní otázky, kterými je třeba se zabývat. Jedna z takových otázek je: má spokojenost ve vztahu souvislost s celkovou životní spokojeností? Diener a Seligman (2002) zkoumali velmi št’astné jedince a porovnávali je s nešt’astnými. Hledali přitom proměnnou, která by byla zároveň dostačující a zároveň nutná pro štěstí. Všichni lidé s touto proměnnou by tedy měli být št’astni a zároveň by jí měli všichni št'astní jedinci. Žádnou takovou proměnnou nenašli, ale našli jednu nutnou proměnnou, a tou byly kvalitní sociální vztahy.

Také je důležité zmínit souvislost mezi spokojeností a stabilitou. Tyto dva konstrukty jdou ve výzkumech často ruku v ruce. Např́íklad Bachandová a Caronová (2001) hovoří o stabilních a št’astných manželství dohromady. Je však třeba dodat, že autoři udali jako podmínky pro svi̊j výběr respondentů jak dlouhodobost vztahu, tak spokojenost obou partnerů. Tak to bývá v mnoha výzkumech št’astných párů - výběr se podmiňuje dlouhodobostí a spokojeností zároveň. Gottman et al. (1998) uvádějí zvlášt’ výsledky pro stabilitu a pro spokojenost. Mnoho faktorů, které měly souvislost se stabilitou, nesouviselo se spokojeností. Vztah těchto dvou konstruktů tedy není zcela jasný. Je evidentní, že stabilní manželství nemusí být nutně št’astné, ale št'astné manželství je vždy stabilní.

Jsme si vědomy toho, že tento výzkum má mnohé problematické body a v ohledech, které přinášely sporné momenty, jsme se často opíraly o dostupnou zahraniční literaturu. Mnohé parametry výzkumu jsme volily na základě srovnání s podobnými studiemi. Do výzkumného souboru byly zařazeny pouze páry, které byly spolu alespoň 10 let. Inspirace k tomu pramení z prací Simsové a Meany (2013) 6,52 let, Rauerové a Vollingové (2013) 8,7 let, Gottmana et al. (1998), kteří zkoumali novomanžele po dobu šesti let nebo Daneshpourové et al. (2011), kde byly páry sezdané alespoň 10 let.

Výzkumný soubor prezentované studie činil 11 párů, tedy 22 respondentů a sběr dat byl ukončen po docílení teoretického nasycení. Podobné počty vidíme také v zahraničních 
podobných výzkumech. Vzorek 11 párů čítal výzkum Simsové a Meany (2010), Daneshpourové et al. (2011), 15 párů měly ve svém šetření Bachandová a Caronová (2001).

Zřejmým nedostatkem, kterému se však v případě kvalitativního šetření lze jen těžko bránit, je nereprezentativnost vzorku. Výběr respondentů probíhal samovýběrem a posléze metodou sněhové koule, protože nalézt jiným způsobem ochotné respondenty, kteří by splňovali daná kritéria, bylo velmi obtížné. Ačkoli jde o nereprezentativní výběr, podařilo se získat rozmanitý výzkumný soubor s respondenty od 28 do 59 let, délkou vztahu od 10 do 38 let, různým dosaženým vzděláním a velikostí místa bydliště.

Věríme, že i přes některé nedostatky přináší tato práce smysluplnou zprávu o českých spokojených párech a bude motivovat další výzkumné snahy v této velmi důležité oblasti psychologického bádání.

\section{LITERATURA}

Allendorf, K. (2012). Marital Quality from a Rural Indian Context in Comparative Perspective. Journal Of Comparative Family Studies, 43(4), 527-544.

Aron, A., Norman, C., C., Aron, E., N., McKenna, C., Heyman, R., E. (2000). Couples shared participation in novel and arousing activities and experienced relationship quality. Journal of Personality and Social psychology, 78(2), 273-284.

Bachand, L. L., \& Caron, S. L. (2001). Ties that Bind: A Qualitative study of Happy Long-Term Marriages. Contemporary Family Therapy: An International Journal, 23(1), 105-121.

Baker, L. R., McNulty, J.K., \& VanderDrift, L. E. (2017). Expectations for future relationship satisfaction: Unique sources and critical implications for commitment. Journal of Experimental Psychology: General, 146(5), 700-721. https://doi.org/10.1037/xge0000299

Bernard, J. (1933). An instrument for the measurement of the succes in marriage. Publications of the American Sociological Society, (39), 194-203.

Bernard, J. (1934). Factors in the distribution of succes in marriage. American journal of sociology, (40), 49-60.

Daneshpour, M., Asoodeh, M., Khalili, S., Lavasani, M., \& Dadras, I. (2011). Self Described Happy Couples and Factors of Successful Marriage in Iran. Journal of Systemic Therapies, vol. 30(issue 2), pp. 43-64. https:// doi.org/10.1521/jsyt.2011.30.2.43.

Davis, K. B. (1929). Factors in the sex life of twenty-two hundred women. Harper \& Brothers, New York.

Demir, M. (2008). Sweetheart, you really make me happy: romantic relationship quality and personality as predictors of happiness among emerging adults. Journal of Happiness Studies, vol. 9(issue 2), pp. 257-277.

Diener, E., \& Seligman, M. (2002). Very Happy People. Psychological Science, 13(1), pp. 81-84.

Gottman, J., \& Gottman, J. (2017). The Natural Principles of Love. Journal of Family Theory and Review, 9(1), 7-26. https://doi.org/10.1111/jtfr.12182.

Gottman, J. M., Coan, J., Carrere, S., \& Swanson, C. (1998). Predicting Marital Happiness and Stability from Newlywed Interactions. Journal Of Marriage \& Family, 60(1), 5-22.

Graham, J., M. (2008). Self-expansion and flow in couples' momentary experiences: An experience samplingstudy. Journal of Personality and Social psychology, 95(3), 679-694.

Kalousová, Z. (2017). Spokojenost v partnerských vztazích. Nepublikovaná diplomová práce. Praha: Univerzita Karlova.

Keizer R. (2014) Relationship Satisfaction. In: Michalos A.C. (eds) Encyclopedia of Quality of Life and Well-Being Research. Springer, Dordrecht. [Vyhledáno 8. 10. 2020 na https://doi.org/10.1007/978-94 -007-0753-5_2455.]

Locke, H. J., \& Wallace, K. M. (1959). Short marital adjustment and prediction tests: Their reliability and validity. Marriage and Family Living, 21, 251-255.

Mikkelson, A., C., \& Pauley, P., P. (2013). Maximizing Relationship Possibilities: Relational Maximization in Romantic Relationships. The Journal of Social Psyhology, 153(4), 467-485.

Rauer, A. \& Volling, B. (2013). More than One Way to be Happy: Typology of Marital Happiness. Family Processes, 52(3), 519-534. 
Sims, K. E., \& Meana, M. (2010). Why Did Passion Wane? A Qualitative Study of Married Women's Attributions for Declines in Sexual Desire. Journal of Sex and Marital Therapy, 36(4), 360-380.

Spanier, G. B. (1976). Measuring dyadic adjustment: New scales for assessing the quality of marriage and similar dyads. Journal of Marriage and the Family, 38, 15-28.

Shrout, M. R., Renna, M. E., Madison, A. A.., Alfano, C. M., Povovski, S. P., Lipari, A. M., Agnese, D. M., Yee, L. D., Carson, I. W. E., \& Kiecolt-Glaser, J. K. (2020). Relationship satisfaction predicts lower stress and inflammation in breast cancer survivors: A longitudinal study of within-person and between-person effects. Psychoneuroendocrinology, 118. https://doi.org/10.1016/j.psyneuen.2020.104708.

Terman, L. M., \& Johnson, W. B. (1939). Methodology and results of recent studies in marital adjustment. American Sociological Review, 4(3), 307-324.

Wallerstein, J. S. (1996). The psychological tasks of marriage: Part 2. American Journal Of Orthopsychiatry, 66(2), 217-227.

Peter J. Ward, Neil R. Lundberg, Ramon B. Zabriskie \& Kristen Berrett (2009) Measuring Marital Satisfaction: A Comparison of the Revised Dyadic Adjustment Scale and the Satisfaction with Married Life Scale, Marriage \& Family Review, 45:4, 412-429, https://doi.org/10.1080/01494920902828219.

Rahn, A., Bennett, C., Jones, T., \& Lykins, A. (2019). Happily partnered older adults‘ relationship-enhancing behaviours. Australian Journal on Ageing, 39(1), 30-39. https://doi.org/10.1111/ajag.12731.

Yedirir, S., \& Hamarta, E. (2015). Emotional Expression and Spousal Support as Predictors of Marital Satisfaction: The Case of Turkey. Educational Sciences: Theory \& Practice, 15(6), 1549-1558.

Zuzana Kalousová, katedra psychologie, Filozofická fakulta UK, e-mail: zuzana.kalousova @.ff.cuni.cz

Iva Štětovská, katedra psychologie, Filozofická fakulta UK, e-mail: iva.stetovska@ff.cuni. $c z$ 